\title{
POPULATION DYNAMICS OF Cyrtomon luridus BOHEMAN (COLEOPTERA: CURCULIONIDAE) ON Duboisia sp. (SOLANACEAE) IN BRAZIL
}

\author{
Paulo Tironi ${ }^{1 *}$; Adrian von Treuenfels ${ }^{1}$; José Roberto Postali Parra ${ }^{2}$ \\ ${ }^{1}$ Solana Agropecuária Ltda, C.P. 01 - 86700-970 - Arapongas, PR - Brasil. \\ ${ }^{2}$ USP/ESALQ - Depto. de Entomologia, Fitopatologia e Zoologia Agrícola, C.P. 9 - 13418-900 - Piracicaba, SP - \\ Brasil. \\ *Corresponding author <tironi@sao.boehringer-ingelheim.com>
}

\begin{abstract}
Cyrtomon luridus (Boheman) has adapted to the medicinal plant Duboisia sp., introduced from Australia. Its larvae feed on roots, causing up to $100 \%$ mortality damages. The population dynamics and biological cycle were studied to determine future control methods in Duboisia sp., in Arapongas, Paraná State, Brazil, from 1993 to 1996. C. luridus presented annual life cycle in Duboisia sp. under natural conditions. The larval development period was 120 to 150 days, from January to May, reaching an average size of 19.0 $\pm 2.0 \mathrm{~mm}$ in soil depth ranging on $24.9 \pm 8.6 \mathrm{~cm}$ to $45.0 \pm 10.0 \mathrm{~cm}$. The beginning of the pupal phase happened in April. The larval-adult viability ranged on $7.5 \%$ to $19.6 \%$. The typical symptoms of attack appeared in an infestation level of 60 larvae per plant. The first adults came out in July, six months after larvae hatching. However, adults came out from soil only in September, at the beginning of the rainy season, reaching the peak of emergency in October, outspreading until January. In laboratory $\left(25^{\circ} \mathrm{C}, 70 \%\right.$ R.H. $)$, females longevity averaged $113.7 \pm 15.2$ days. In this period, laying capacity was $42.7 \pm 7.9$ egg masses, with $9.4 \pm 0.61$ eggs each, totaling $402 \pm 72.9$ eggs per female. Adults $C$. luridus were found parasitized by Microctonus sp. (Loan) (Hymenoptera: Braconidae). Solanaceae species Solanum mauritianum Scopoli and Cestrum intermedium Sendt. were identified as host plants of $C$. luridus.
\end{abstract}

Key words: Microctonus, biological cycle, medicinal plant, control, longevity

\section{DINÂMICA POPULACIONAL DE Cyrtomon luridus BOHEMAN (COLEOPTERA: CURCULIONIDAE) EM Duboisia sp. (SOLANACEAE) NO BRASIL}

\begin{abstract}
RESUMO: Cyrtomon luridus (Boheman) adaptou-se à planta medicinal Duboisia sp., introduzida da Austrália, na qual causa danos de até $100 \%$. A dinâmica populacional e o ciclo biológico foram estudados de 1993 a 1996, em Arapongas, PR, Brasil, com o objetivo de determinar futuros métodos de controle em Duboisia sp.. C. luridus apresentou ciclo anual em Duboisia sp. em condições naturais. O período de desenvolvimento larval ocorreu em 120 a 150 dias, de janeiro a maio, atingindo o tamanho médio de $19.0 \pm 2.0 \mathrm{~mm}$ a uma profundidade média no solo de $24.9 \pm 8.6 \mathrm{~cm}$ a $45.0 \pm 10.0 \mathrm{~cm}$. Em abril, foi observado o início da fase pupal. A viabilidade do período larval-adulto variou de $7.5 \%$ a $19.6 \%$. Os sintomas típicos de ataque apareceram com o nível de infestação de 60 larvas por planta. Os primeiros adultos surgiram em julho, seis meses após a eclosão das larvas. Entretanto, o início da emergência de adultos do solo foi em setembro, no início da estação chuvosa, atingindo o pico de emergência em outubro, estendendo-se até janeiro. Em laboratório $\left(25^{\circ} \mathrm{C}, 70 \% \mathrm{UR}\right)$, a longevidade média das fêmeas foi de $113.7 \pm 15.2$ dias. Neste período, cada fêmea colocou $42.7 \pm 7.9$ massas de ovos com $9.4 \pm 0.61$ ovos cada, totalizando uma média de $402 \pm 72.9$ ovos por fêmea. Adultos de C. luridus foram encontrados parasitados por Microctonus sp. (Loan) (Hymenoptera: Braconidae). As espécies de Solanaceae Solanum mauritianum Scopoli e Cestrum intermedium Sendt. foram encontradas como plantas hospedeiras de C. luridus.

Palavras-chave: Microctonus, ciclo biológico, planta medicinal, controle, longevidade
\end{abstract}

\section{INTRODUCTION}

Six species of the genus Cyrtomon (Coleoptera, Curculionidae, Naupactini) occur in Neotropical regions. Within Brazil, Cyrtomon luridus (Boheman) was recorded in the States of Paraná, Santa Catarina and Rio Grande do
Sul, and Cyrtomon gibber (Boheman) was recorded in São Paulo, Minas Gerais and Rio de Janeiro (Lanteri, 1990). These species develop in wild Solanaceae, as well as on cotton and eucalyptus (Sérgio A. Vanin - University of São Paulo, personal communication) and alfalfa (Lanteri et al., 1994). C. luridus is a rootworm. Its larvae feed on the roots 
in the soil, and adults feed on plant leaves. It has adapted to, and seriously damages the medicinal plant, Duboisia sp. (Solanaceae) (hybrid between Duboisia myoporoides F. Muell and Duboisia leichhardtii R. Brown) (Ohlendorf, 2002), causing up to $100 \%$ mortality. Introduced from Australia, this plant is rich in scopolamine, an alkaloid widely used for human and animal health.

Although C. luridus is not considered an important pest for other commercial crops in Brazil, its potential to become a pest must be evaluated. For instance, other Naupactini species, genus Naupactus and Pantomorus, closely related to Cyrtomon, are considered important pests in Brazilian citrus (Gravena et al., 1992; Guedes, 2003). Because C. luridus causes extensive damage to Duboisia sp., research was undertaken to investigate its population dynamics and biology, aiming to determine future control methods on Duboisia sp.

\section{MATERIAL AND METHODS}

Field and laboratory studies were carried out on Duboisia sp. plantations, from 1993 to 1996, in Arapongas, northern Paraná State, Brazil (23⒉ $27^{\prime}$ ' S; $\left.51^{\circ} 21^{\prime} .55^{\prime} \mathrm{W}\right)$. A laboratory broadstock $\left(25 \pm 2^{\circ} \mathrm{C}\right.$ and $70 \pm 10 \%$ R.H.) was maintained to provide larvae and eggs. Adult C. luridus collected in the field from Duboisia sp. were placed in groups of 10-15 in rearing containers $(200 \mathrm{~mm}$ height $\times 100 \mathrm{~mm}$ diameter PVC tubes), along with Duboisia sp. leaves as a food source.

The larval development in the soil was evaluated in January 1995, when 30, 12-months old Duboisia sp. plants were infested with 40 newly-hatched, first instar C. luridus larvae, reared in laboratory. Plants were kept inside individual nylon mesh cages $(1.80 \times 1.80 \times 1.80$ $\mathrm{m})$, to isolate them from natural infestation of $C$. luridus. Five plants were pulled out of the soil monthly during six months after infestation, and larvae length $(\mathrm{mm})$ and soil depth $(\mathrm{cm})$ were measured. The number of larvae, pupae and adults in the soil were also evaluated, and data presented as average \pm standard deviation.

Signals of $C$. luridus infestation and larval-adult viability were studied under field conditions, in January 1995, when 12-months old Duboisia sp. plants were inoculated with either 10, 20, 40 or 60 newly hatched firstinstar $C$. luridus larvae per plant $(\mathrm{n}=5)$, in a totally randomized experimental design. Plants were isolated from natural infestation as described. Evaluations were made based on typical signals of attack (yellowish and leaf fall), and by counting the number of adults that emerged from each plant. These results were also used to determine the mean larval-adult viability under field conditions, data presented as average \pm standard deviation.

The emergence period and the soil emergence rate of adults C. luridus on Duboisia sp. was studied under field conditions from August 1995 to January 1996. Ten, 24- month old Duboisia sp. plants naturally infested, were cut at soil level and immediately covered with a nylon mesh cage $(1.40 \times 1.80 \times 0.20 \mathrm{~m})$. Adults emerging from those 10 plants were collected in a daily basic basis and the emergence period was determined, according to the rainfall.

The fluctuation of adults on foliage and search behavior of adult $C$. luridus on Duboisia sp. foliage was monitored under field conditions from 1993 to 1995, by inspecting $1 \%$ of plants fortnightly for one minute each. The mean adult number per 1000 plants was calculated monthly and adult samples were maintained in the laboratory for observations on occurrence of parasitism. The C. luridus search behavior was studied in field condition, adults being observed to be flier or walker during this period.

In September 1995, recently-emerged, adult $C$. luridus $(\mathrm{n}=65$ pairs $)$ from the field, were maintained individually ( 1 male +1 female) in rearing containers ( 25 $\pm 2{ }^{\circ} \mathrm{C}$ and $70 \pm 10 \%$ R.H), along with Duboisia sp. leaves as a food source, renewed every two days. The preoviposition period, egg laying capacity and the female longevity were evaluated till the death, and data presented as average \pm standard deviation. The alternative host plants for $C$. luridus were investigated in the neighboring areas of the Duboisia sp. plantation. Wild Solanaceae plants were inspected monthly in 1994 to find C. luridus larvae in the roots or adults in the leaves, to determine the alternative hosts for $C$. luridus in the forest.

\section{RESULTS AND DISCUSSION}

The larval mean size was $3.0 \pm 1.31 \mathrm{~mm}$ in February, 30 days after infestation, and reached $19.0 \pm 2.0$ $\mathrm{mm}$ in May, 150 days after infestation, before pupal stage. Larval were found in soil depth ranging on $24.9 \pm 7.18$ $\mathrm{cm}$ in the beginning to $45.0 \pm 10.0 \mathrm{~cm}$ at the end of development (Figure 1). The pupal phase started in April, 90 days after infestation, when the first pupa was found, and reached a peak in June. The first adults $C$. luridus appeared in the soil in July, 180 days after infestation, similar to Naupactus cervinus Boheman in citrus, in which egg to adult period ranged from 162 to 240 days (Guedes, 2003).

Table 1 - Adult $C$. luridus emergence, after inoculation with larvae on Duboisia sp., at different rates, under field conditions.

\begin{tabular}{lrrrcc}
\hline Infestation rate & $\mathrm{n}$ & Mean $\pm \mathrm{SD}$ & Min. & Max. & $\begin{array}{c}\text { Larval-adult } \\
\text { viability }\end{array}$ \\
\hline (larvae per plant) & & & & & $\%$ \\
10 & 5 & $1.4 \pm 1.14$ & 0 & 3 & 14.0 \\
20 & 5 & $3.6 \pm 1.67$ & 2 & 6 & 18.0 \\
40 & 5 & $7.6 \pm 3.21$ & 4 & 12 & 19.0 \\
60 & 5 & $11.8 \pm 4.76$ & 7 & 19 & 19.7 \\
\hline
\end{tabular}


The typical signals of attack (yellowish and leaf fall) appeared only in one plant, in the most infested level (60 larvae per plant). In this infestation level, an average $11.8 \pm 4.76$ adult beetles emerged in September, 270 days after infestation (Table 1). Larval-adult viability ranged from $14.0 \%$ (10 larvae per plant) to 19.7\% (60 larvae per plant), with $17.7 \%$ in average, indicating a high larvalpupa mortality. Although the cause of high mortality was not studied in this work, Barker (1988) found 66\% mean larval mortality of Listronotus bonariensis (Kuschel) caused by desiccation of first-instars larvae and by competition among $2^{\text {nd }}$ instars larvae searching for the best food (Barker et al., 1989a).

The first adult $C$. luridus emerged in September, at the beginning of the rainy season, with peak of emergence during the first half of October, continuing until January at a lower rate (Figure 2). The same was observed by Guedes (2003) for Naupactus species on Citrus sp., in Brazil. The higher emergence rate was observed at high humidity levels, after rains, as observed in October; short dry periods decreased the emergence rate, as observed in November. In this study, an average 59.4 adults emerged per plant from September 1995 to January 1996. As pupal phase peak was found to be June, this is probably the C. luridus diapause phase.

The methodology used in this work did not allow determining the permanence of adult C. luridus in the soil, after the emergence from the pupal phase. However, this behavior is typical of Naupactini species and low soil mois-

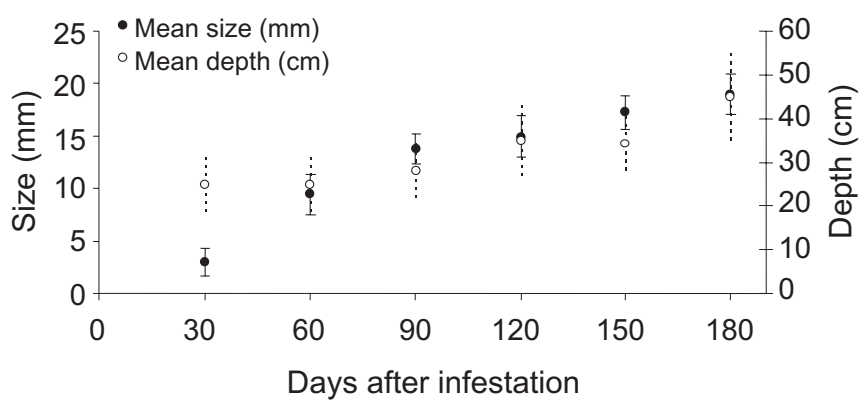

Figure 1 - Mean size and mean depth in the soil of $C$. luridus larvae infesting Duboisia sp., measured monthly after artificial infestation in the field, from January to July.

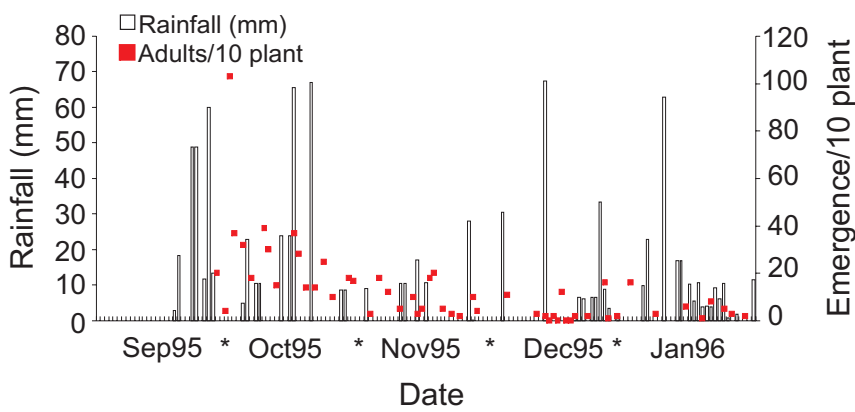

Figure 2 - Emergence of C. luridus adults from Duboisia sp. and rainfall from September 1995 to January 1996. ture can delay larval development, and lead to desiccation, death, and difficulties to move in the soil (Silveira Neto et al., 1976; Loiácono \& Marvaldi, 1994; Guedes, 2003).

Adult $C$. luridus were easily found on the top of foliage branches and leaves of Duboisia sp., mainly from October to April, and quite rarely from May to September. The population fluctuation of adult weevils on Duboisia sp. foliage, measured from 1993 to 1996, associated with the survey of the different phases in the soil, demonstrated that $C$. luridus has an annual life cycle (univoltine) (Figure 3), like do most of Naupactini in Argentina (Lanteri et al., 1994), Uruguay (Alzugaray et al., 1998), USA (Florida), and Antilles (Woodruff, 1985). Adult C. luridus collected in the field and kept in the laboratory were found parasitized by Microctonus sp. (Loan) (Hymenoptera: Braconidae) up to 54\% (Tironi et al., 2004).

Adult $C$. luridus were found to be good walkers on soil surface, searching for food and not for mating, as described for L. bonariensis (Barker et al., 1989b; Goldson, 1981; Goldson et al., 1999). Flights of $C$. luridus were observed to be very short, only few meters, indicating that this insect is not a good flier, as is the genus Naupactus, which is incapable of flying due to poorly-developed metathoraxic wings and fused wing covers (Lanteri \& Marvaldi 1995).

The pre-oviposition period was $24.0 \pm 2.8$ days, indicating the need of feeding and also mating before egg laying start. In comparison to other Naupactini species, the period was longer than $N$. cervinus (11.6 days) and Naupactus versatilis Hustache (6.7 days), as described by Guedes (2003) on citrus. Although usually reported for Naupactini species (Lanteri \& Normark, 1995; Lanteri \& Marvaldi, 1995), parthenogenesis was not observed for C. luridus in this work.

The egg-phase period of C. luridus was 25 to 30 days and was observed that larvae prefer higher moisture to eclode. In comparison, Guedes (2003) found 22.4 and 23.5 days for $N$. cervinus and $N$. versatilis, respectively, and closed to Naupactus sp. (Zehnder, 1997).

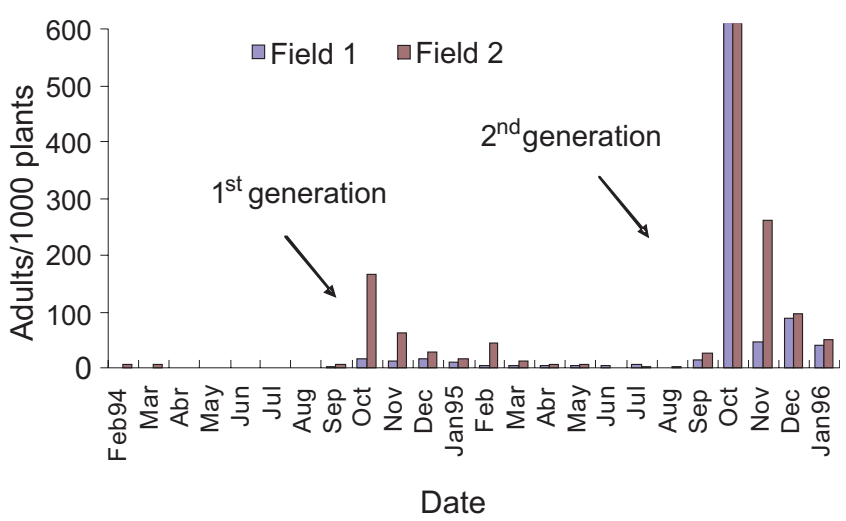

Figure 3 - Population fluctuations of adult C. luridus on Duboisia sp., from February 1994 to January 1996, in the field (planted in 1993). 
The $C$. luridus oviposition last 16 weeks, peaking on seven to 12 weeks after emergence (Figure 4). Female longevity was $113.7 \pm 15.2$ days in average. In this period, the egg-laying capacity was $42.7 \pm 7.9 \mathrm{egg}$ masses, with $9.4 \pm 0.61$ eggs per mass $(n=200)$, totaling $402 \pm 72.9$ eggs per female.

Masaki \& Kadoi (1997) for Pantomorus cervinus (Boheman), found a mean of 1238, 1004 and 416 eggs laid per female on Arachis hypogaea L., Rubus sp. (Tourn.) and Citrus natsudaidai Haiata respectively, and mean longevities of 136, 116 and 86 days on these same plant species, respectively. In this case, the number of eggs per female and the longevity were more influenced by the plant on which the adults fed than on the host roots on which the larvae developed, in agreement with Ottens \& Todd (1979) and Guedes (2003), for Naupactus species. In addition, Pantomorus viridisquamosus (Boheman), when fed on leaves of Trifolium repens L. (Fabaceae) and Taraxacum officinale L. (Asteraceae), began oviposition after 63-69 days, laying 164 eggs in 90 days, with adult longevity of 102 to 240 days (Loiácono \& Diaz, 1995).

Effects of density and temperature on the $C$. luridus oviposition were not studied in this work. However, McNeill et al. (1998) found significant decline in the number of eggs per plant produced by L. bonariensis, with increased adult densities, which are in turn affected by temperature.

Two wild Solanaceae species were found as alternative host plants of C. luridus, on the edge of Duboisia sp. plantations. C. luridus larvae were found mainly in the roots of Solanum mauritianum Scopoli, locally known as "fumo-bravo" or "capoeira-branca", and the second species was Cestrum intermedium Sendt., known as "coerana". These perennial plant species are widely distributed throughout Paraná state and seems to be important for the survival of $C$. luridus in the native forests. Curculionids attacking medicinal plants were re-

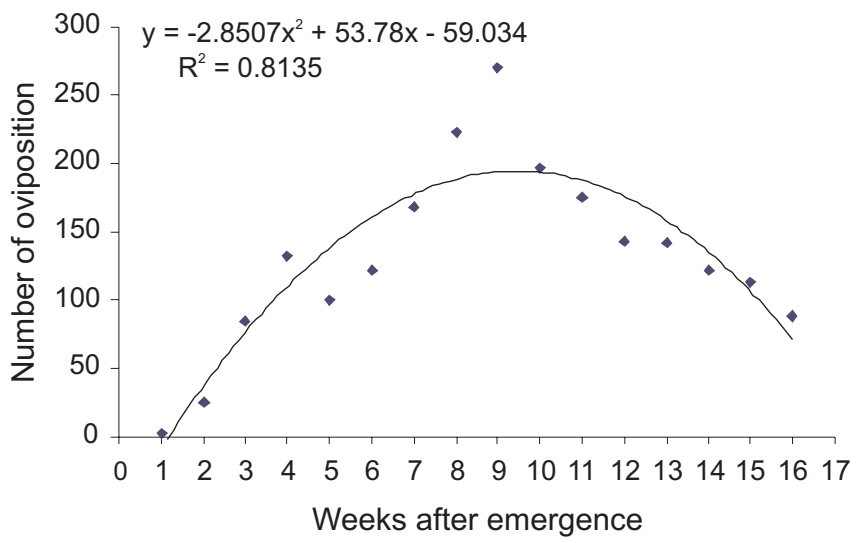

Figure 4 - Oviposition period of C. luridus, under laboratory conditions, after emergence in the field ( $\mathrm{n}=65$ pairs). Temperature $25 \pm 2{ }^{\circ} \mathrm{C}$ e RH $70 \pm 10 \%$. ported by Martin (1999), who found Pantomorus cervinus on Solanum aviculare and Solanum laciniatum, plants known in New Zealand as poroporo, utilized for the extraction of solasodine.

\section{ACKNOWLEDGEMENTS}

We thank Dr. Sérgio A. Vanin (Universidade Federal de São Carlos, SP) for determining Cyrtomon luridus; Dr. Robert A. Wharton (Texas A\&M University) for determining Microctonus sp. and Dr. Ésio de Pádua Fonseca (Universidade Estadual de Londrina, PR) for determining Solanaceae species. We also thank the laboratory staff of the Departamento de Entomologia, Fitopatologia e Zoologia Agrícola - USP/ESALQ, and all research assistants who helped with the experiment. This study was supported by Boehringer Ingelheim, through Fundação de Estudos Agrários Luiz de Queiroz, Piracicaba, SP, Brasil.

\section{REFERENCES}

ALZUGARAY, R.; RIBEIRO, A.; ZERBINO, M.S.; MORELLI, E.; CASTIGLIONI, E Situación de los insectos del suelo en Uruguay. In: AVANCES EN EL ESTUDIO DE LA DIVERSIDAD, IMPORTANCIA E MANEJO DE LOS COLEÓPTEROS EDAFÍCOLAS AMERICANOS, 5., Puebla, 1998. Memorias. Puebla: SME; BUAP, 1998. p.151-164.

BARKER, G.M. Effect of temperature on development and survival of Argentine stem weevil (Listronotus bonariensis) immature stages. New Zealand Journal of Zoology, v.15, p.387-390, 1988.

BARKER, G.M.; POTTINGER, R.P.; ADDISON, P.J. Population Dynamics of the Argentine Stem Weevil Listronotus bonariensis in pastures of Waikato. New Zealand Agricultural, Ecosystems and Environment, v.26, p.79-115, 1989a.

BARKER, G.M.; POTTINGER, R.P.; ADDISON, P.J. Flight behavior of Listronotus bonariensis (Coleoptera: Curculionidae) in the Waikato, New Zealand. Environmental Entomology, v.18, p.996-1005, 1989b.

GOLDSON, S.L. Non-reproductive determination of migratory flight in Argentine stem weevils, Listronotus bonariensis. Physiology Entomology, v.6, p.283-288, 1981.

GOLDSON, S.L.; PROFFITT, J.R.; BAIRD, D.B. Listronotus bonariensis (Coleoptera: Curculionidae) flight in Canterbury. Bulletin of Entomological Research, v.89, p.423-431, 1999.

GUEDES, J.V.C. Identificação e bioecologia dos curculionídeos-das-raízes dos citros de São Paulo e Minas Gerais. Piracicaba: USP/ESALQ, 2003. 95p. (Tese - Doutorado).

GRAVENA, S.; CORREIA, A.C.B.; YAMAMOTO, P.T.; MUNUERA, M.C.M.; SALVA, R.A. Pantomorus \& Naupactus, uma ameaça a citricultura. Jaboticabal: UNESP,CEMIP, 1992. 9p. (Boletim Técnico, 2).

LANTERI, A.A. Revisión sistemática del género Cyrtomon Schönherr (Coleoptera, Curculionidae). Revista Brasileira de Entomologia, v.34, p.387-402, 1990.

LANTERI, A.A.; MARVALDI, A.E. Graphognathus Buchanan: a new synonym of Naupactus De-jean and systematics of the $N$. leucoloma species group (Coleoptera: Curculionidae). The Coleopterist Bulletin, v.49, p.206-228, 1995.

LANTERI, A.A.; NORMARK, B.B. Parthenogenesis in the tribe Naupactini (Coleoptera: Curculionidae). Annals of the Entomological Society of America, v.88, p.722-731, 1995.

LANTERI, A.A.; DÍAZ, N.B.; MORRONE, J.J. Identificación de las espécies. In: LANTERI, A.A. (Ed.). Bases para el control integrado de los gorgojos de la alfalfa. La Plata: De la Campana Ediciones, 1994. p.3-40. 
LOIÁCONO, M.S.; DIAZ, N.B. Description of eggs and first instar larvae of Pantomorus viridisquamosus (Boheman) with data on its life history (Coleoptera, Curculionidae). Revista Brasileira de Entomologia, v.39, p.633-639, 1995.

LOIÁCONO, M.S.; MARVALDI, A.E. Biología y daños ocasionados. In: LANTERI, A.A. (Ed.). Bases para el control integrado de los gorgojos de la alfalfa. La Planta: De la Campana Ediciones, 1994. p.49-55.

MARTIN, N.A. Arthropods and molluscs associated with poroporo (Solanum aviculare and S. laciniatum): an annotated species list. Journal of the Royal Society of New Zealand, v.29, p.65-76, 1999.

MASAKI, M.; KADOI, M. Host plants of Pantomorus cervinus (Boheman) and relationship between fecundity or longevity and its host plants. Research Bulletin of the Plant Protection Service, v.33, p.1-6, 1997.

MCNEILL, M.R.; BAIRD, D.B.; GOLDSON, S.L. Evidence of densitydependent oviposition behavior by Listronotus bonariensis (Coleoptera: Curculionidae) in Canterbury pasture. Bulletin of Entomological Research, v.88, p.527-536, 1998.

OHLENDORF, W. Domestication and crop development of Duboisia spp. (Solanaceae). Disponível em : <http://www.fao.org/docrep/w3735e/ w3735e23.htm>. (08 out. 2002).
OTTENS, R.J.; TODD, J.W. Effects of host plant on fecundity, longevity, and oviposition rate of a whitefringed beetle. Annals of the Entomological Society of America, v.72, p.715-719, 1979.

SILVEIRA NETO, S.; NAKANO, O.; BARDIN, D. Manual de ecologia dos insetos. São Paulo: Editora Ceres, 1976. 419p.

TIRONI, P.; TREUENFELS, A. von; PARRA, J.R.P. Biology of Microctonus sp. (Hymenoptera; Braconidae), a parasitoid of Cyrtomon luridus Boh. (Coleoptera; Curculionidae). Scientia Agricola, v.61, p.538-541, 2004.

WOODRUFF, R.E. Citrus weevils in Florida and West Indies: preliminary report on systematics, biology and distribution (Coleoptera: Curculionidae). Florida Entomologist, v.68, p.370-379, 1985

ZEHNDER, G.W. Population dynamics of whitefringed beetle (Coleoptera: Curculionidae) on sweet potato in Alabama. Environmental Entomology, v.26, p.727-735, 1997.

Received October 10, 2004

Accepted February 01, 2005 